\title{
JEJAK BAHASA PROTO-AUSTRONESIA PADA PRASASTI GUNUNG TUA (LOKANĀTHA)
}

\section{TRACES OF PROTO-AUSTRONESIAN LANGUAGE ON THE GUNUNG TUA INSCRIPTION (LOKANĀTHA)}

\author{
Churmatin Nasoichah¹, Dwi Widayati², dan Mulyadi² \\ ${ }^{1}$ Balai Arkeologi Sumatera Utara, Jl. Seroja Raya Gg. Arkeologi No. 1, Tanjung Selamat Medan Tuntungan, Medan, Sumatera Utara, \\ Indonesia; posel: curma.oke@gmail.com; churmatin.nasoichah@kemdikbud.go.id. \\ 2Pascasarjana Linguistik, Universitas Sumatera Utara, Medan, Indonesia; posel: dwi_dayati@yahoo.co.id; mulyadi@usu.ac.id
}

\begin{abstract}
Abstrak. Pada prasasti Gunung Tua (Lokanātha) ditemukan sejumlah kata yang mengindikasikan bahasa Proto-Austronesia. Jejak bahasa Proto-Austronesia tersebut berupa kata turunan dan/atau kalimat-kalimat, yang dapat dianalisis pada tataran fonologi, morfologi, dan sintaksis. Permasalahan penelitian ini adalah mengetahui tataran fonologi dan morfologi bahasa ProtoAustronesia pada prasasti Gunung Tua (Lokanātha), dan tataran sintaksis dari struktur kalimat bahasa Melayu kuno pada prasasti tersebut. Tujuan penelitian ini untuk memahami signifikasi bahasa Proto-Austronesia pada Prasasti Gunung Tua (Lokanātha). Metode penelitian ini bersifat kualitatif yang dijabarkan secara deskriptif, serta analisis data yang dilakukan dengan metode padan dan agih. Hasil penelitian menunjukkan bahwa pada tataran fonologi, terdapat dua kata, yaitu juru atau 'orang pandai', dan pānḍai atau 'pandai (terampil)'. Pada tataran morfologi, ditemukan dua kata, yaitu tatkala atau 'ketika', dan barbwat atau 'membuat'. Ternyata, kata juru dan tatkala merupakan kata serapan dari bahasa Sanskerta, sedangkan kata pānḍai dan barbwat merupakan kata turunan dari bahasa Proto-Austronesia. Berdasarkan tataran sintaksis, dapat disimpulkan bahwa struktur kalimat pada prasasti Gunung Tua (Lokanātha) berbentuk kalimat aktif transitif atau kalimat yang memerlukan objek.
\end{abstract}

Kata kunci: Prasasti Gunung Tua, Lokanatha, Proto-Austronesia, Linguistik historis komparatif, Fonologi, Morfologi, Sintaksis

\begin{abstract}
The Gunung Tua (Lokanātha) inscription contained words indicating the Proto-Austronesian language. Traces of the Proto-Austronesian language were evident from derivative words and/or sentences written in the inscription, and these could be analyzed at levels of phonology, morphology, or syntax. This research was carried out to recognize the phonological and morphological level of the Proto-Austronesian language on the Gunung Tua (Lokanātha) inscription, and the syntactic level of sentence structure of the ancient Malay language. The purpose of this study was to understand the significance of the Proto-Austronesian language in the Gunung Tua (Lokanätha) inscription. This research method is qualitative, and data were portrayed descriptively. Data analysis was carried out using methods of identity and distributional. Research results showed that at the phonological level, two words were recognized, which were 'juru' or smart person, and 'pāndai' or smart (skilled). At the morphological level, two words were identified, which were 'tatkala' or when, and 'barbwat' or make. Apparently, the words 'juru' and 'tatkala' were loanwords from Sanskrit, while the words 'pāndai' and 'barbwat' were derivative words of the Proto-Austronesian language. At a syntactic level, it could be concluded that the sentence structure of the Gunung Tua (Lokanātha) inscription was transitive active.
\end{abstract}

Keywords: Gunung Tua inscription, Lokanātha, Proto-Austronesian, Comparative historical linguistics, Phonology, Morphology, Syntax

\section{PENDAHULUAN}

Bahasa Proto-Austronesia merupakan bahasa tua yang menurunkan sejumlah bahasa serumpun yang memiliki persebaran jumlah penutur terbesar di dunia, mulai dari Samudra Pasifik, Samudra Hindia, bahkan dari pantai Afrika, Vietnam, Taiwan, Hawaii Pulau Paskah, sampai ke Selandia Baru (Adelaar 2000). Bahasa ProtoAustronesia merupakan salah satu rumpun bahasa yang berasal dari kawasan Asia daratan. Bukti arkeologis menunjukkan bahwa komunitas masyarakat penutur Bahasa Proto-Austronesia pertama hidup sekitar 8.000 
tahun yang lalu di pesisir Cina (Taiwan) kemudian bercabang menjadi berbagai jenis bahasa pada kurang lebih 6.000 tahun yang lalu (Adelaar 2010).

Sebaran bahasa Proto-Austronesia di Nusantara dibagi menjadi dua, yaitu sub rumpun Austronesia Barat dan Austronesia Timur (Keraf 1996). Pulau Sumatra yang merupakan bagian dari sub rumpun Austronesia Barat memiliki beberapa varian bahasa di antaranya: a) Bahasa Aceh; b) Bahasa Batak (termasuk Gayo); c) Bahasa Melayu (pesisir timur Sumatra, tengah, dan bagian barat) termasuk Bahasa Minangkabau, Kerinci, Pulau Bangka dan Kepulauan Belitung; d) Bahasa Rejang; e) Bahasa Lampung; f) bahasa pulau perbatasan (dituturkan di pulau-pulau barat Sumatra termasuk Simeulue, Nias, dan Siberut), dan g) Bahasa Enggano, yang lokasinya berada di Samudra Hindia (Provinsi Bengkulu) (Adelaar 2010).

Bahasa Melayu memiliki sebaran penutur terbesar di Pulau Sumatra. Pada perkembangannya dari bahasa Proto-Austronesia, Bahasa Melayu memiliki beberapa perubahan bentuk, baik disebabkan oleh pengaruh dari dalam maupun pengaruh bahasa asing. Para ahli bahasa membagi perkembangan Bahasa Melayu menjadi tiga tahap, yakni Bahasa Melayu Kuno yang mendapat pengaruh Sanskerta dan kebudayaan Hindu; Bahasa Melayu Klasik yang mendapat pengaruh Bahasa Arab dan kebudayaan Islam; serta Bahasa Melayu Modern yang lebih banyak dipengaruhi kebudayaan kolonial dari barat, terutama Inggris (Pusposari 2017).

Bahasa Melayu Kuno dikenal pada awal Masehi (M) sampai dengan abad ke-14 M dengan pengaruh bahasa asing yang didominasi dari India, terutama bahasa Sanskerta. Di Provinsi Sumatera Utara bukti penggunaan Bahasa Melayu Kuno telah ditemukan pada sejumlah prasasti, salah satunya adalah Prasasti Gunung Tua (Lokanātha). Prasasti Gunung Tua (Lokanātha) ditemukan di kawasan kepurbakalaan HinduBuddha Padang Lawas, tepatnya di Gunung Tua, Kabupaten Padang Lawas Utara. Prasasti ini ditulis pada media logam dengan Aksara Sumatra Kuno dan menggunakan bahasa Sanskerta dan Bahasa Melayu Kuno (Nasoichah 2009).

Penelusuran jejak Bahasa Proto-Austronesia pada penulisan Prasasti Gunung Tua (Lokanātha) tersebut terdapat beberapa kata dan kata turunannya yang dapat dianalisis menggunakan satu kajian linguistik historis komparatif (disingkat LHK) berdasarkan tataran fonologi dan morfologi. Pada tataran sintaksis, juga akan dilakukan untuk mengetahui struktur kalimat Bahasa Melayu Kunonya. Hal ini dilakukan karena dalam kajian LHK data yang dibandingkan minimal harus dua bahasa pada masa yang berbeda. Berdasarkan pemahaman tersebut, permasalahan penelitian ini adalah: a) bagaimanakah jejak Bahasa Proto-Austronesia pada Prasasti Gunung Tua (Lokanātha) berdasarkan tataran fonologi dan morfologi? serta b) bagaimanakah struktur kalimat Bahasa Melayu Kuno Prasasti Gunung Tua (Lokanātha) pada tataran sintaksis? Tujuan penelitian ini adalah pemahaman eksistensi Bahasa Proto-Austronesia pada Prasasti Gunung Tua (Lokanātha) yang berbahasa Melayu Kuno. Penelitian terkait jejak Bahasa Proto Austronesia pada sejumlah prasasti berbahasa Melayu kuno dapat dikatakan sebagai penelitian baru pada bidang ilmu arkeologi (epigrafi).

Manusia memerlukan bahasa dalam berkomunikasi. Bahasa adalah alat untuk menyampaikan suatu ide, pikiran, hasrat, dan keinginan kepada orang lain dan berperan dalam perkembangan berbagai macam aspek kehidupan manusia. Bahasa memiliki fungsi, yakni sebagai media dalam penyampaian informasi (Arsyad 2018). Penelitian sejarah bahasa merupakan penelitian yang dilakukan dengan cara mereka-ulang bahasa proto yang telah menurunkan bahasa yang ada sampai saat ini. Bahasa-bahasa proto yang berkembang pada masa lalu berubah menjadi beberapa bahasa turunan disebabkan oleh tempat dan waktu. Bahasa-bahasa turunan yang berkembang, berbeda dengan bahasa asalnya dan terjadi secara turun-temurun (Adhiti 2019).

LHK merupakan suatu kajian bahasa yang mempermasalahkan bahasa dalam kurun waktu tertentu serta mengkaji perubahan-perubahan yang terjadi. Fokus kajian LHK adalah mengamati data suatu bahasa sekurangnya dalam dua periode. Data tersebut kemudian dibandingkan agar mendapatkan kaidah-kaidah perubahan yang terjadi (Keraf 1996). Kajian LHK pada tataran fonologi paling sering digunakan sebagai dasar penentuan perbandingannya. Hal ini dikarenakan pada rekonstruksi tersebut 'kata' menjadi kunci dalam melakukan analisis, dan melalui 'kata' seasal itulah fonem dan perubahannya ditemukan (Ino 2015). Hanya pada struktur kata, perubahan setiap fonem dengan varian-variannya itu terjadi (Leben dan Robinson 1977). Penggabungan sumber data prasasti dengan kajian LHK, dilakukan untuk mengkaji sumber data prasasti terutama dalam segi kebahasaan untuk mencari bahasa protonya. 
Pada tataran fonologi terdapat beberapa bentuk perubahan bunyi dari bahasa protonya. Adapun perubahan bunyi tersebut di antaranya: a) pewarisan linear yang merupakan proses perubahan bunyi, yang tetap mempertahankan bentuk protonya; dan b) perubahan inovasi yang merupakan proses yang mengalami perubahan dalam bahasa sekarang (Nasoichah 2020; Keraf 1996). Perubahan-perubahan tersebut dapat berupa asimilasi atau disimilasi. Asimilasi, yaitu proses perubahan bunyi yang menyebabkan bunyi lain berubah sehingga akhirnya keduanya menjadi lebih mirip (Crowley dan Bowern 2010). Disimilasi, yaitu proses perubahan bunyi dari satu suara yang berubah menjadi seperti suara lain di dekatnya (Crowley dan Bowern 2010). Berdasarkan tempatnya terdapat beberapa jenis bentuk perubahan bunyi (Crowley dan Bowern 2010), di antaranya adalah adanya proses: a) penghilangan suatu fonem, baik di awal kata (apheresis), di tengah kata (syncope), maupun di akhir kata (apocope); b) penambahan suatu fonem, baik di awal kata (prothesis), di tengah kata (epenthesis atau anaptyxis), maupun di akhir kata (paragog); dan c) pertukaran tempat dua fonem (metathesis) (Keraf 1996).

Pada tataran morfologi terdapat rekonstruksi bentuk perubahan yang menggunakan satu metode yang disebut dengan rekonstruksi internal (Crowley dan Bowern 2010). Rekonstruksi tersebut digunakan untuk mendapatkan bentuk-bentuk protonya, di antaranya: a) adanya alomorf, yaitu suatu kata yang terdiri atas morfem bebas dan morfem terikat dalam mempersoalkan bentuk morfem terikatnya pada bahasa protonya; $b$ ) netralisasi, yaitu kondisi hilangnya kontras antara dua fonem dalam lingkungan fonologi tertentu; c) reduplikasi, yaitu proses perulangan unsur kata; dan d) bentuk infleksi, yaitu perubahan unsur kata yang menggambarkan berbagai hubungan gramatikal (Keraf 1996).

Pada tataran sintaksis, analisis akan sulit dilakukan secara diakronis terutama dalam mencari bentuk bahasa protonya. Hal ini disebabkan suatu kalimat dapat dengan mudah digantikan dengan kata-kata lainnya. Pada perubahan fonologi dan morfologi, fonem memiliki tempat yang sudah ditetapkan dalam suatu kata dan hanya dapat diganti satu sama lain dalam keadaan terbatas. Ketika mengkaji secara sintaksis, aturan pada struktur kalimat menjadi hal yang penting. Beberapa ahli berpendapat bahwa untuk mengkaji perubahan sintaksis dalam kaitannya dengan sejarah bahasa tidak akan sama dengan cara analisis sintaksis pada umumnya (Crowley dan Bowern 2010). Pada tataran sintaksis dalam penelitian ini tidak akan dilakukan perbandingan bahasa antara Bahasa Melayu Kuno dan Bahasa Proto-Austronesia. Keputusan ini diambil karena tidak adanya referensi terkait bentuk kalimat dalam bentuk protonya.

Pada penelitian ini hanya dilakukan untuk mencari struktur kalimat Bahasa Melayu Kuno dengan menerapkan teori X-bar. Teori X-bar ini digunakan karena bersifat universal dan bertujuan untuk menyederhanakan suatu bahasa. Teori X-bar menjelaskan struktur umum, baik frasa maupun kalimat yang direpresentasikan pada skema X-bar. Hubungan antara kategori leksikal dan frasa atau kalimat digambarkan dalam dua tataran proyeksi. Jika kategori leksikal seperti N (Nomina), V (Verba), A (Adjektiva), atau P (Preposisi) disimbolkan dengan $X$, serta dibentuk oleh komplemen, keterangan, dan spesifier. Komplemen yang berkombinasi dengan $\mathrm{X}$ akan membentuk proyeksi $\mathrm{X}$-bar, Keterangan yang berkombinasi dengan $\mathrm{X}$-bar akan membentuk proyeksi $X$-bar yang lebih tinggi. Spesifier yang berkombinasi dengan $X$-bar akan membentuk proyeksi maksimal X (Haegeman 1994).

\section{METODE}

Metode penelitian ini bersifat kualitatif-deskriptif. Metode kualitatif adalah cara yang dilakukan dalam sebuah penelitian untuk mengkaji objek penelitian secara ilmiah yang peneliti atau penulis berperan inti (penting) dalam proses analisisnya. Objek penelitian dijabarkan secara deskriptif agar hasilnya dapat berupa narasi berdasarkan fakta yang ada. Penelitian ini dilakukan dalam beberapa tahapan di antaranya data dikumpulkan, lalu dianalisis dengan menggunakan teori-teori yang sesuai, yaitu LHK dan X-bar, serta terakhir hasil analisis tersebut disajikan dalam bentuk interpretasi dan simpulan.

Analisis data penelitian dilakukan menggunakan metode agih serta padan. Metode padan dilakukan dengan membandingkan semua unsur penentu dan unsur data yang relevan (Sudaryanto 2015). Objek sasaran penelitian ditetapkan berdasarkan tingginya kadar keselarasan, kesepadanan, kecocokan, kesesuaian, atau kesamaannya dengan alat penentu serta menjadi standarnya (Sudaryanto 2015). Sementara itu metode agih, bagian bahasa itu sendiri berfungsi sebagai alat penentu. Alat penentu tersebut dapat berupa kata (preposisi, 
adverbia, verba, nomina, atau yang lainnya), fungsi sintaksis (subjek predikat objek keterangan atau SPOK atau yang lainnya), klausa, dan lainnya (Sudaryanto 2015).

Teknik penelitian yang digunakan di sini berupa teknik hubung banding menyamakan hal pokok, ketika teknik banding sendiri dilakukan secara diakronis menggunakan pendekatan top-down reconstruction (Sudirman 2005). Istilah banding (komparatif) menunjukkan proses kerjanya dengan membandingkan satu data dengan data lainnya melalui ada tidaknya kesamaan atau perbedaan komponen-komponen bahasa yang diatur berdasarkan asas-asas tertentu (Sudaryanto 1992).

Data yang telah ditemukan berupa 'kata', 'kata turunan' dan 'kalimat' dari sumber data prasasti, kemudian diklasifikasikan berdasarkan tataran fonologi, morfologi, dan sintaksis. Data berupa 'kata' akan dianalisis pada tataran fonologi dengan metode padan, yaitu membandingkannya dengan Bahasa Proto-Austronesia. Data berupa 'kata turunan' akan dianalisis pada tataran morfologi dengan metode agih sehingga diketahui asal katanya, lalu dengan metode padan dibandingkan dengan bahasa protonya. Data yang berupa 'kalimat' akan dianalisis pada tataran sintaksis dengan menggunakan metode padan.

\section{HASIL DAN PEMBAHASAN}

Prasasti Gunung Tua (Lokanātha) (Gambar 1) merupakan prasasti pada arca perunggu yang ditulis pada bagian belakang lapik arca. Ketika ditemukan, prasasti ini dijadikan pusaka oleh salah seorang Raja Huta yang ada di wilayah Sumatera Utara tepatnya di Gunung Tua. Prasasti tersebut kini menjadi koleksi Museum Nasional dengan No. Inventaris 3309 atau 626d, sedangkan replikanya (Gambar 2) disimpan di Museum Negeri Prov. Sumatera Utara. Prasasti tersebut ditulis pada tahun 961 Saka atau abad ke-11 (30 Maret 1039 Masehi) (Damais 1955; Griffiths 2014; Utomo 2007). Prasasti ini sudah pernah dilakukan alih aksara dan bahasa (Bosch 1930; Setianingsih dkk. 2003) sebagai berikut:

"Swastinśaka warșātita 961 caitramāsa, tithi tritiyansukla, śekrawāra, tatkālanjuru pāṇdai suryya barbwat bhatāra lokanātha, imānikuśala mūlā ni sarvva satva sādhāranikrtvā, anu ttarā yām samyayakram bodhau parināmam yāmi"

terjemahan: "Selamat tahun Śaka 961, bulan Caitra, hari ketiga masa bulan terang, hari Jumat, ketika juru pandai yang bernama Suryya membuat (patung) bhatāra Lokanātha, dari semua pekerja yang baik dari segala pembuatan, harapan saya bagi semua kebijaksanaan yang tinggi dan lengkap"
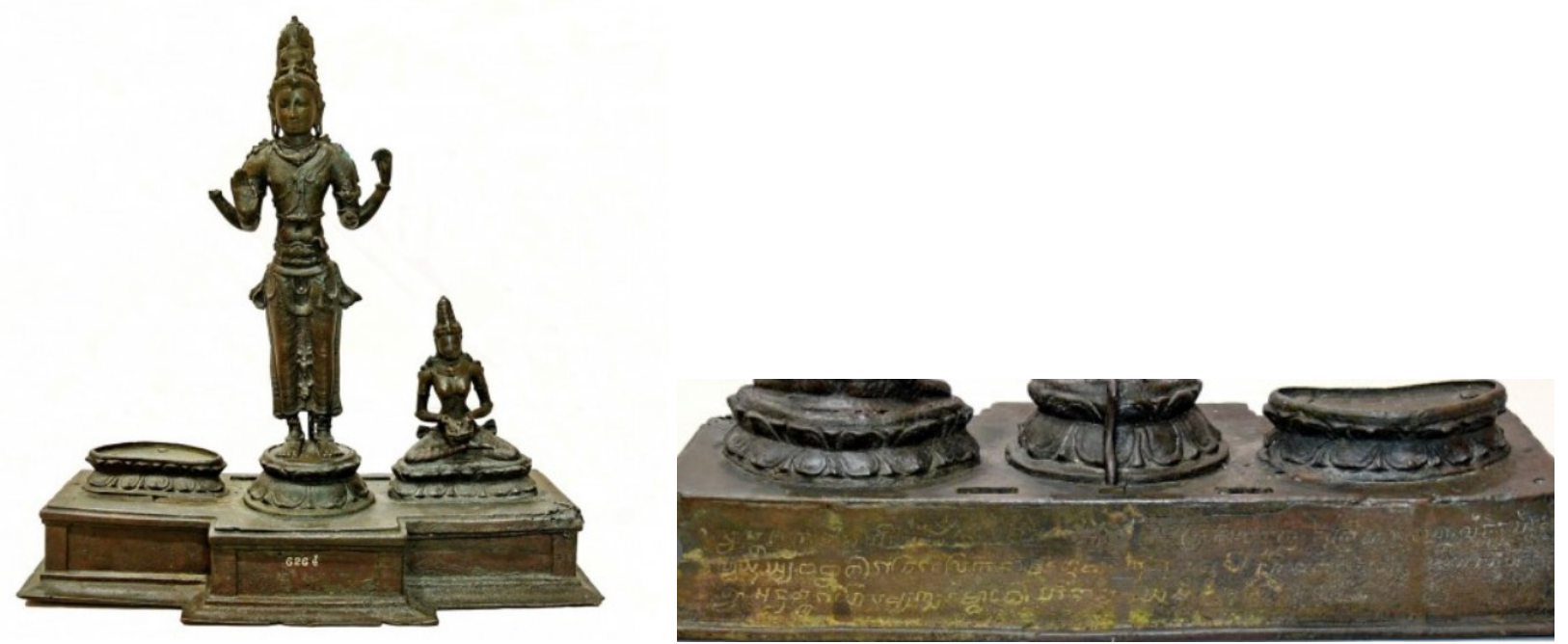

Sumber: Utomo 2017 (https://arkenas.kemdikbud.go.id/contents/read/article/rvh06b_1510555637/bhataralokanatha-dari-gunung-tua\#gsc.tab=0)

Gambar 1 Prasasti Gunung Tua (Koleksi Museum Nasional); tampak depan (kiri), tampak belakang (kanan) 


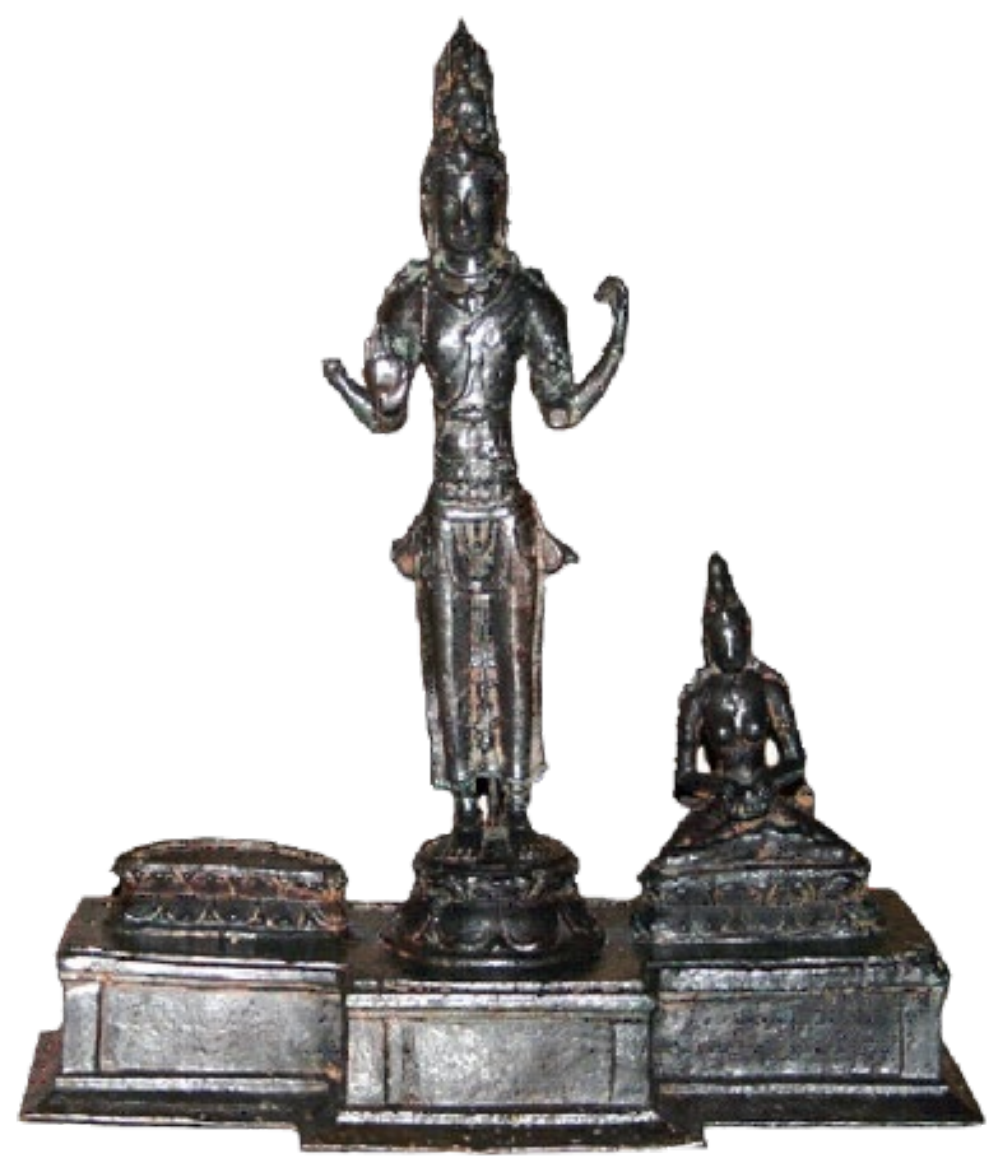

Sumber: Balai Arkeologi Sumatera Utara 2009

Gambar 2 Replika Prasasti Gunung Tua (Koleksi Museum Negeri Prov. Sumatera Utara; tampak depan)

Terkait dengan penelusuran jejak Bahasa Proto-Austronesia pada penulisan Prasasti Gunung Tua (Lokanatha), terdapat sejumlah kata dan kata turunan berbahasa Melayu Kuno yang dapat dianalisis berdasarkan kajian LHK pada tataran fonologi dan morfologi. Adapun sejumlah kata dan kata turunan yang ditemukan sebagai berikut:

1. Pada tataran fonologi diketahui dua kata berbahasa Melayu Kuno di antaranya kata juru atau 'orang pandai' dan kata pāṇụai atau 'pandai (terampil)'.

2. Pada tataran morfologi diketahui dua kata berbahasa Melayu Kuno, yaitu kata barbwat atau 'membuat' dan kata tatkāla atau 'ketika'.

Terkait struktur kalimat Bahasa Melayu Kuno pada penulisan Prasasti Gunung Tua (Lokanatha), ditemukan satu kalimat yang dapat dianalisis pada tataran sintaksis, yaitu: "...tatkāla juru pāṇ̣ai suryya barbwat bhatāra lokanātha...".

\section{Tataran Fonologi}

Secara etimologis fonologi berasal dari dua kata yaitu phōné yang berarti bunyi, dan lógos yang berarti ilmu. Fonologi adalah ilmu yang mempelajari pola bunyi suatu bahasa. Ilmu fonologi mempelajari variasi bunyi, aturan dalam pengurutan dan distribusi bunyi ucapan, dapat dihubungkan dengan komponen lain seperti aturan yang dapat mencirikan pola suara dalam memberikan informasi yang ada di dalamnya (Hayes 2009). Menurut Verhaar (2012) fonologi adalah bidang ilmu linguistik yang mempelajari, menganalisis, dan membicarakan bunyi-bunyi bahasa menurut fungsinya. Dua bunyi yang secara fonetis berbeda dikatakan mempunyai perbedaan fonologis bila perbedaan tersebut menyebabkan perbedaan makna antara dua kata tersebut. Pada tataran fonologi ini terdapat kata berbahasa Melayu Kuno, yaitu kata juru atau 'orang pandai' dan kata pāṇ̣ai atau 'pandai (ahli)'. Adapun analisis pada tataran fonologi sebagai berikut. 
Kata juru atau 'orang pandai' dalam Bahasa Melayu Kuno ini bukanlah turunan dari Bahasa ProtoAustronesia. Kata juru atau 'orang pandai' ini merupakan kata serapan dari Bahasa Sanskerta, yaitu dari kata jūr atau 'tua (jompo atau orang tua)' (Monier-Williams 1956:423). Kata juru atau 'orang pandai' ini dalam penyerapan katanya mengalami perubahan bunyi dengan penambahan fonem di akhir kata atau disebut dengan paragog. Selain itu, hilangnya bentuk vokal panjang /ūl menjadi bentuk vokal pendek /ul. Adapun proses perubahan bunyinya dapat dilihat pada Gambar 3.

Dari segi makna kata juru mengalami penyempitan makna dari makna serapannya. Pada Bahasa Sanskerta kata jūr memiliki makna 'menjadi tua atau jompo atau orang tua', kemudian setelah diserap ke dalam Bahasa Melayu Kuno berubah menjadi 'orang yang pandai atau ahli dalam suatu jenis pekerjaan yang memerlukan kecakapan, latihan, maupun kecermatan'. Orang pandai yang dimaksud dalam Bahasa Melayu Kuno tersebut kemungkinan juga termasuk orang yang sudah tua karena untuk menjadi seorang yang ahli (pandai) memerlukan waktu yang lama sehingga memiliki kemiripan makna dengan bahasa asalnya.

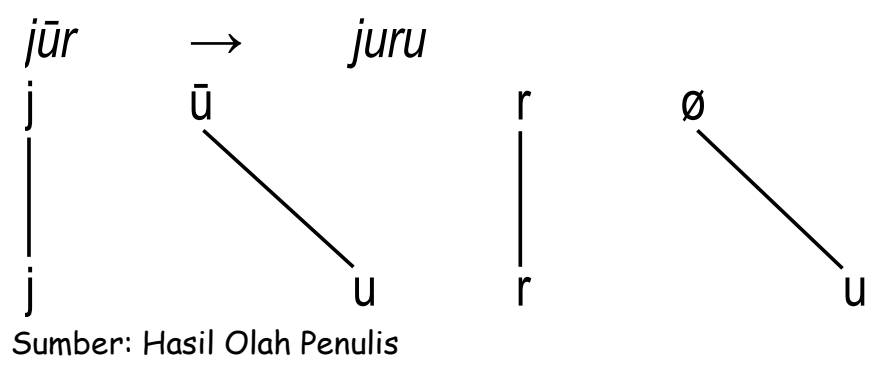

Gambar 3 Perubahan bunyi pada kata juru

Data kedua pada tataran fonologi adalah kata pāṇ̣ai atau 'pandai (terampil)'. Kata pāṇ̣ai atau 'pandai (terampil)' dalam Bahasa Melayu Kuno ini merupakan turunan dari Bahasa Proto-Austronesia, yaitu dari kata "panḍai atau 'pandai (terampil)' (Wurm and Wilson 1975). Tanda bintang (*) digunakan untuk menunjukkan bentuk dari Bahasa Proto-Austronesianya. Kata *pandai atau 'pandai (terampil)' ini dalam perkembangannya telah mengalami perubahan bunyi, yaitu bunyi vokal pendek /a/ berubah menjadi bunyi vokal panjang /āl. Pada tata Bahasa Proto-Austronesia dan Melayu Kuno sebenarnya tidak mengenal adanya bentuk vokal panjang seperti /āl, |ül, |īl, dan sebagainya. Munculnya vokal panjang pada Bahasa Melayu Kuno ini disebabkan adanya pengaruh Bahasa Sanskerta yang dalam sistem fonologi bahasa tersebut mengontraskan antara vokal panjang dan vokal pendek. Adapun proses perubahan bunyinya dapat dilihat pada Gambar 4. Selain tidak mengalami perubahan bunyi fonem, kata pāṇại juga tidak mengalami perubahan makna dari makna aslinya yang tetap bermakna 'pandai (terampil)'.

\section{*paṇạai $\rightarrow$ pāṇ̣ai 'awal/mulai'}
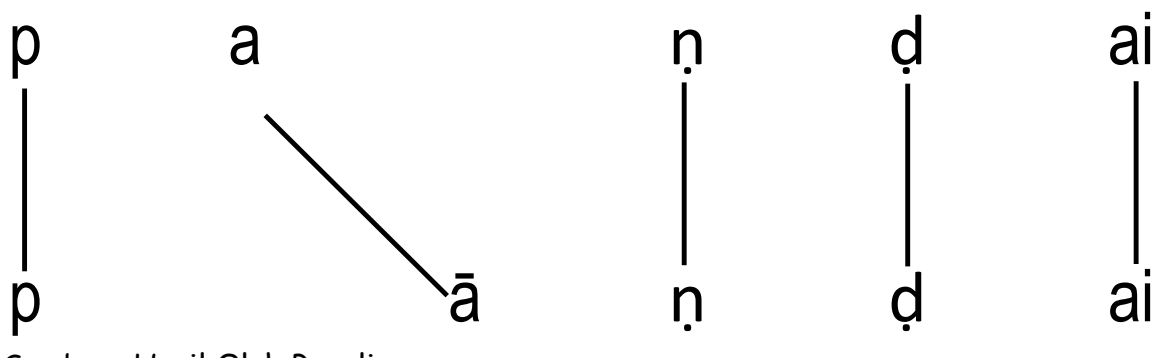

Gambar 4 Perubahan bunyi pada kata pāṇ̣ai

Dari kedua kata berbahasa Melayu Kuno tersebut ternyata tidak semuanya merupakan turunan dari Bahasa Proto-Austronesia, tetapi ada yang merupakan kata serapan dari Bahasa Sanskerta. Penyerapan Bahasa Sanskerta ke dalam Bahasa Melayu Kuno tersebut tidak serta-merta terserap begitu saja, tetapi juga disesuaikan dengan tata bahasa yang dimiliki sebelumnya, yaitu Bahasa Melayu Kuno yang merupakan turunan 
dari Bahasa Proto-Austronesia. Hal ini terbukti dengan hilangnya bunyi vokal panjang menjadi bunyi vokal pendek. Pada Bahasa Sanskerta, bunyi vokal panjang dan vokal pendek berfungsi untuk membedakan makna suatu kata, sedangkan dalam Bahasa Melayu Kuno yang merupakan turunan dari Bahasa Proto-Austronesia perbedaan vokal panjang dan pendek tersebut tidak berfungsi untuk membedakan makna suatu kata.

\section{Tataran Morfologi}

Secara etimologi kata morfologi berasal dari kata morphē yang berarti bentuk, dan kata lógos yang berarti ilmu. Morfologi adalah ilmu yang mempelajari pengaturan morfem dengan semua kombinasi dan susunannya dalam membentuk kata (Nida 1949). Pada kajian morfologi, kata dibentuk baik oleh afiksasi, klitika, reduplikasi maupun kata majemuk (kata-kata yang terdiri atas dua atau lebih morfem bebas atau pangkalan terikat) yang memiliki struktur internal (Lieber 2009). Pada tataran morfologi ini terdapat dua kata turunan berbahasa Melayu Kuno, yaitu kata barbwat atau 'membuat' dan tatkāla atau 'ketika'. Adapun analisis pada tataran morfologi sebagai berikut.

Data pertama yaitu kata barbwat atau 'membuat' merupakan bentuk polimorfemik dengan bar- pada kata barbwat tersebut dilesapkan. Terjadi rekonstruksi internal dengan adanya alomorf, yaitu adanya pelesapan baryang akhirnya diketahui bentuk morfem bebas dari kata barbwat adalah bwat. Analisis tersebut menghasilkan beberapa bentuk morfem, yaitu morfem bebas bwat atau 'membuat' dan morfem terikat bar-. Morfem terikat barmerupakan prefiks (awalan) dari morfem bebas bwat.

Kata bwat dalam Bahasa Melayu Kuno ini merupakan turunan dari Bahasa Proto-Asutronesia, yaitu dari kata *bu'at atau 'membuat' (Wurm dan Wilson 1975). Kata *bu'at atau 'membuat' dalam perkembangannya mengalami proses asimilasi labialisasi. Perubahan yang terjadi pada bunyi fonem / $u$ l yang merupakan bunyi vokal tidak bisa serta-merta berubah menjadi fonem yang berupa konsonan /w/ sebab bunyi vokal tidak bisa mewarisi bunyi konsonan. Bunyi /u'al pada kata *bu'at dalam pengucapannya menjadi /buwatl. Fonem yang berupa konsonan $/ w /$ tersebut muncul sebagai pelancar bunyi. Adapun bentuk perubahan bunyinya sebagai berikut: *bu'at $\rightarrow$ bwat atau 'membuat'. Dari segi makna, kata bwat tidak mengalami perubahan makna dari makna protonya yang tetap bermakna 'membuat'.

Prefiks (awalan) bar- pada kata barbwat atau 'membuat' tersebut merupakan bentuk morfem terikat yang sering ditemukan pada prasasti-prasasti berbahasa Melayu kuno, terutama dari masa Sriwijaya sejak abad ke$7 \mathrm{M}$. Pada bahasa-bahasa yang merupakan sub rumpun Austronesia Barat, bentuk prefiks (awalan) bardan/atau ber- ini sebagian besar telah menjadi mar- (misalnya dalam Bahasa Batak pada kata marlojong atau 'berlari'). Terdapat juga prasasti di Jawa Barat, yaitu Prasasti Kebon Kopi II (abad 10 Masehi) yang menggunakan prefiks (awalan) bar- dan mar- dalam satu teks prasasti (Benjamin 2009). Analisis dari Benjamin (2009) tersebut menunjukkan bahwa prefiks (awalan) mar- telah berkembang menjadi bar- (atau mungkin mbar), kemudian berubah menjadi ber-. Adelaar (1992) menjelaskan perkembangan dari bentuk prefiks (awalan) bardan mar-, seperti berikut: " $m A r->+m(A) r->+m b A r->+b A r->$ bar-, ba-, bə-, dan bar-. Dari keterangan tersebut dapat disimpulkan bahwa bentuk dari prefiks (awalan) bar- pada Bahasa Proto Austronesia adalah * $m A r-$.

Data kedua pada tataran morfologi adalah kata tatkāla atau 'ketika'. Kata tatkāla 'ketika' dalam Bahasa Melayu Kuno tersebut bukanlah turunan dari Bahasa Proto Austronesia. Kata tatkāla atau 'ketika' atau prasasti lain menyebutnya dengan tatakāla ini merupakan kata serapan dari Bahasa Sanskerta, merupakan bentuk polimorfemik yang terdiri atas dua morfem, yaitu tāt atau 'jadi' (Monier-Williams 1956) dan kālá atau 'waktu' (Monier-Williams 1956) sehingga menjadi tātkālá. Kata tatkāla atau 'ketika' ini dalam penyerapannya mengalami perubahan bunyi atau disebut dengan pewarisan inovasi, yaitu fonem /āl yang tidak lagi dibunyikan panjang sehingga menjadi fonem /al. Adapun skema perubahan bunyinya dapat dilihat pada Gambar 5. 


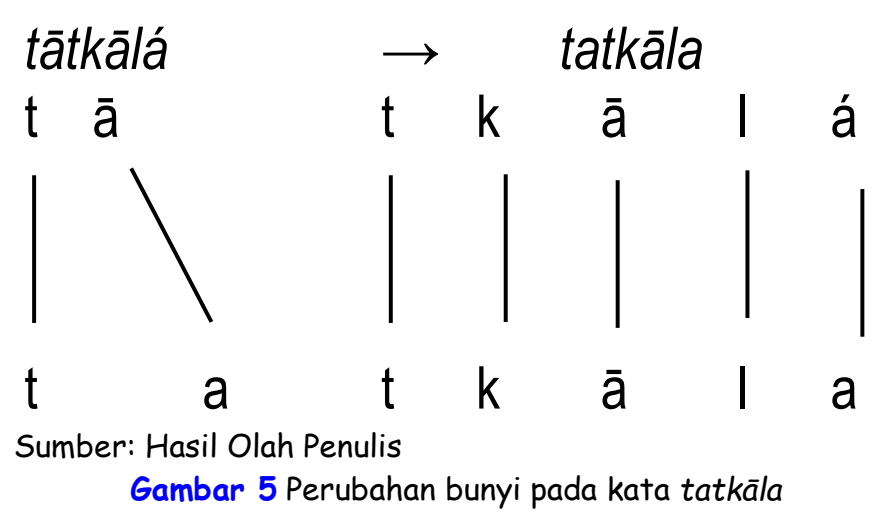

Berdasarkan makna, kata tatkāla yang semula terdiri atas dua morfem, yaitu tāt yang bermakna 'jadi' dan kālá yang bermakna 'waktu' atau menyatakan waktu, pada proses penyerapan ke dalam Bahasa Melayu Kuno menjadi satu morfem bebas tatkāla yang bermakna 'ketika' dan secara harfiah berbeda makna, tetapi keduanya memiliki makna yang sama, yaitu menyatakan keterangan waktu.

Kedua kata turunan berbahasa Melayu Kuno tersebut, setelah dilakukan analisis pada tataran morfologi diketahui bahwa tidak semuanya merupakan turunan dari Bahasa Proto Austronesia, tetapi ada juga yang merupakan kata serapan dari Bahasa Sanskerta. Pada kata barbwat atau 'membuat' yang terbentuk dari morfem bebas bwat atau 'membuat' dan morfem terikat bar- ternyata keduanya merupakan turunan dari Bahasa Proto Austronesia. Kata tatkāla atau 'ketika' merupakan bahasa serapan dari Bahasa Sanskerta yang dibentuk oleh dua morfem, tetapi dalam proses penyerapannya tersebut telah berubah menjadi satu bentuk morfem bebas.

\section{Tataran Sintaksis}

Secara etimologi sintaksis berasal dari Bahasa Yunani Kuno, yaitu súntaxis yang berarti 'susunan' atau 'tersusun secara bersama'. Sintaksis merupakan tata bahasa yang membahas hubungan gramatikal antarkata di dalam kalimat atau dalam tuturan. Kalimat ada dua macam, pertama disebut klausa yang terdiri atas satu verba saja disertai satu atau lebih konstituen yang secara sintaktis berhubungan dengan verba tersebut; kedua, kalimat majemuk yang terdiri atas dua klausa atau lebih dan tersusun sedemikian rupa sehingga klausa-klausa tersebut memiliki satu satuan intonasi saja dan bergabung satu dengan lainnya secara sintaktis (Verhaar 2012).

Terkait struktur kalimat Bahasa Melayu Kuno pada penulisan Prasasti Gunung Tua (Lokanatha) ini tidak akan dikaitkan dan dibandingkan dengan bentuk protonya. Analisis dilakukan untuk mengetahui struktur kalimat yang digunakan pada penulisan prasasti tersebut. Berdasarkan prasasti tersebut diketahui adanya satu kalimat berbahasa Melayu kuno yang berbunyi: “...tatkāla juru pānḍai suryya barbwat bhatāra lokanātha...".

Metode padan referensial digunakan dalam menganalisis tataran sintaksis ini dengan menggunakan teknik pilah unsur penentu. Dengan adanya daya pilah tersebut, akan diketahui beberapa referen yang ada, misal pada data yang berupa kalimat berbahasa Melayu Kuno tersebut merupakan bagian dari satu rangkaian kalimat yang terdiri atas beberapa kalimat berbahasa Sanskerta di antaranya:

(1) Svasti śaka varșātita 946 caitramāsa, tithi tritiya sukla, śekrawāra;

(2) tatkāla juru pānội suryya barbwat bhatāra lokanātha;

(3) imānikuśala mūlā ni sarvva satva sādhāranikrtvā;

(4) anu ttarā yām samyayakram bodhau parināmam yāmi.

Pada kalimat (1) berisi keterangan waktu yang berupa angka tahun, nama bulan, tanggal, dan hari. Pada kalimat tersebut tidak ditemukan verba sebagai penanda suatu kalimat sehingga hanya berfungsi sebagai penanda waktu. Kalimat (2), bentuknya ditandai oleh adanya verba transitif yang berbunyi barbwat atau 'membuat (memproduksi)' sehingga memerlukan objek bhatāra lokanātha atau '(patung) dewa Lokanātha'. Kalimat (3) dan (4) berupa keterangan tambahan yang berisi harapan dari proses yang telah dilakukan pada 
kalimat (2). Keempat rangkaian kalimat tersebut dapat disimpulkan bahwa induk kalimat terletak pada kalimat (2). Kalimat (2), apabila dianalisis berdasarkan teori X-bar dapat dilihat pada Gambar 6. Berdasarkan analisis di atas menggunakan teori X-bar dapat diketahui kaidah dari kalimat berbahasa Melayu Kuno pada Prasasti Gunung Tua (Lokanātha), yang struktur kalimatnya sebagai berikut.

$$
\mathrm{K} \rightarrow \mathrm{FAdv}+\text { Spes + I + Komp }
$$

Hasil analisis di atas menunjukkan bahwa prasasti tersebut memiliki struktur tata Bahasa, yaitu terdiri atas Frasa Adverbial (FAdv) yang berfungsi sebagai keterangan waktu, Frasa Nominal (FN) sebagai subjek dan objek, dan Frasa Verbal (FV) sebagai predikat yang berbentuk transitif. Pada kalimat tersebut terdapat adanya beberapa pembagian kelas kata, yaitu:

a) Pada awal kalimat (2) ini ditandai dengan adanya Frasa Adverbial (FAdv), yaitu kata tatkāla atau 'ketika'. Makna 'ketika' akan tidak sesuai apabila ditempatkan pada kalimat tersebut karena menjadikan induk kalimat terkesan tidak berdiri sendiri dan terlihat seperti anak kalimat. Oleh sebab itu, dalam mengartikan kalimat tersebut diperlukan adanya pronomina 'itu' sehingga menjadi 'ketika itu'. Keterangan tersebut juga menunjukkan bahwa dalam tata bahasa Melayu Kuno tidak ditemukan penggunaan pronomina dalam menunjukkan induk dari suatu kalimat;

b) Pada kalimat (2) tersebut terdapat dua bentuk Frasa Nomina (FN), yaitu juru pāṇạai suryya yang berfungsi sebagai subjek dan bhatāra lokanātha yang berfungsi sebagai objek. Frasa Nomina (FN) yang berfungsi sebagai subjek tersebut dalam teori X-bar merupakan bentuk spesifier, sedangkan Frasa Nomina (FN) yang berfungsi sebagai objek tersebut merupakan bentuk dari komplemennya;

c) Bentuk kalimat (2) ini ditandai dengan adanya Frasa Verbal (FV) yang berbunyi barbwat atau 'membuat (memproduksi)'. Kata barbwat atau 'membuat (memproduksi)' dalam Bahasa Melayu Kuno merupakan verba transitif, yaitu verba yang memerlukan objek. Sebaliknya, dalam Bahasa Melayu sekarang atau bahasa Indonesia, kata yang memiliki morfem bar- atau ber- justru digunakan untuk verba intransitif atau yang tidak memerlukan objek.

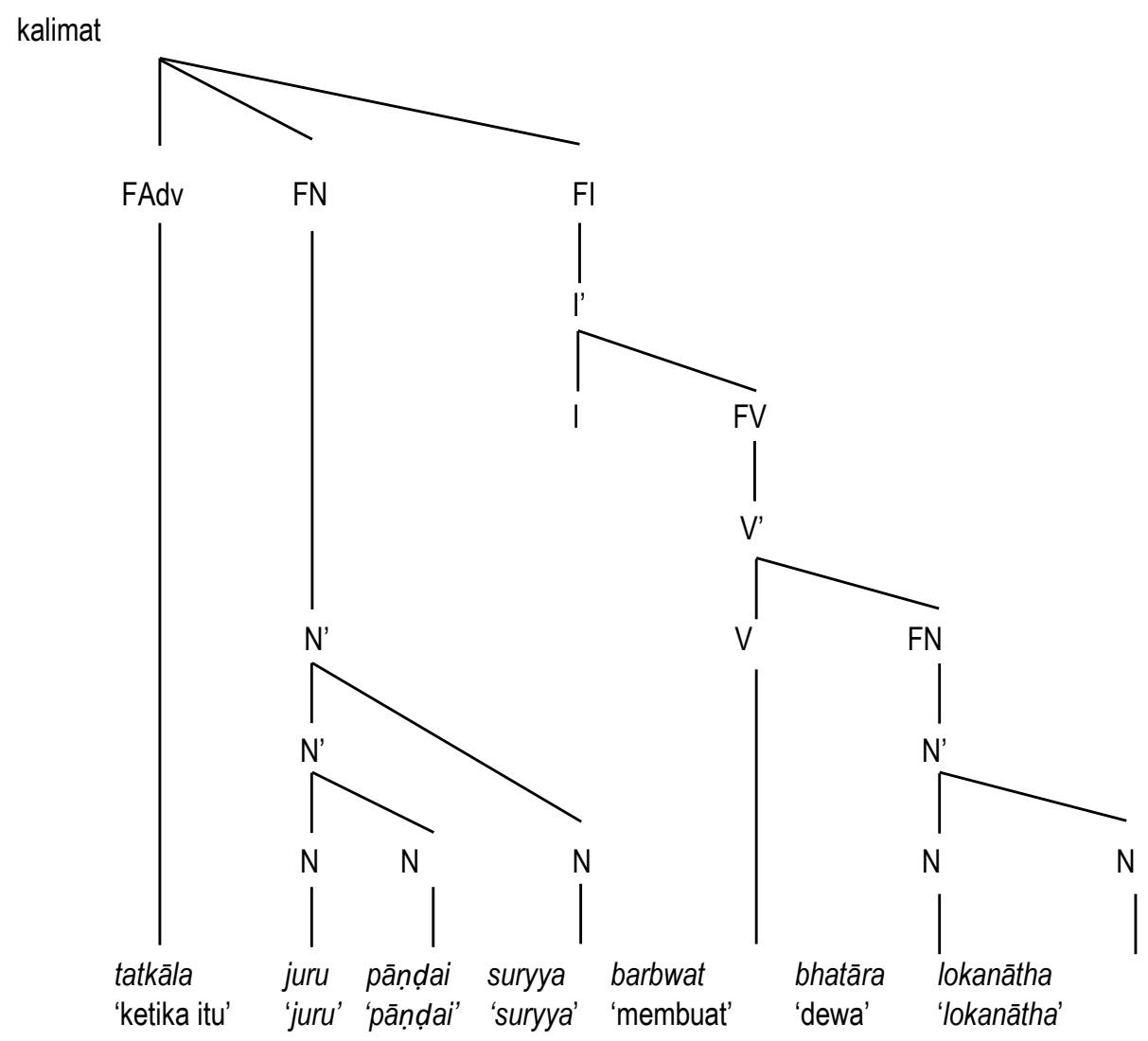

Sumber: Hasil Olah Penulis

Gambar 6 Analisis X-bar pada Kalimat 
Dari hasil analisis prasasti dengan pendekatan LHK, baik itu pada tataran fonologi, morfologi, maupun sintaksis diketahui bahwa Bahasa Melayu Kuno yang berkembang di wilayah kepurbakalaan Hindu-Buddha Padang Lawas di Sumatera Utara, khususnya pada penulisan Prasasti Gunung Tua (Lokanātha), merupakan turunan bahasa atau perkembangan dari Bahasa Proto-Austronesia. Terdapat beberapa kata seperti pada kata pāṇ̂ai atau 'pandai (terampil)' dan barbwat atau 'membuat' yang ditemukan sebagai bukti adanya penggunaan bahasa turunan Proto-Austronesia. Namun demikian, terdapat juga beberapa kata seperti kata juru atau 'orang pandai' dan tatkāla atau 'ketika' yang merupakan serapan atau pinjaman dari Bahasa Sanskerta.

Bahasa Sanskerta banyak memengaruhi penggunaan Bahasa Melayu terutama pada masa perkembangan kebudayaan Hindu-Buddha di Nusantara. Periode awal perkembangan Bahasa Melayu ini ditandai dengan pengaruh kebudayaan India yang tampak dari penggunaan Aksara Palawa dan turunannya (misalnya Sumatra Kuno) pada Bahasa Melayu Kuno (Hidayatullah 2012). Pada akhirnya beberapa kata dalam Bahasa Melayu Kuno tersebut mendapatkan penambahan-penambahan perbendaharaan kata dari bahasa serapan.

Pada penulisan Prasasti Gunung Tua (Lokanātha) ini masih banyak ditemukan unsur penggunaan Bahasa Sanskerta, baik pada kata, kata turunan, maupun kalimatnya. Kata pinjaman atau serapan pada prasasti tersebut ditemukan hanya empat kata dan hanya dua kata yang merupakan turunan Bahasa Proto-Austronesia. Meskipun demikian, tidak serta-merta Prasasti Gunung Tua (Lokanātha) ini dianggap sebagai prasasti yang ditulis dengan menggunakan Bahasa Sanskerta, misalnya pada kalimat (2): "...tatkāla juru pāṇụi suryya barbwat bhatāra lokanātha...". Sebagian besar kata merupakan serapan dari Bahasa Sanskerta, tetapi dari segi tata bahasanya merupakan struktur kalimat Bahasa Melayu Kuno. Struktur kalimat pada prasasti menunjukkan formula "K $\rightarrow$ FAdv + Spes + I + Komp", dengan Frasa Adverbial (FAdv) berfungsi sebagai keterangan waktu yang diletakkan di depan, yang merupakan ciri dari tata bahasa Melayu Kuno. Selanjutnya, penggunaan Frasa Nomina (FN) berfungsi sebagai subjek, Frasa Verbal (FV) berfungsi sebagai predikat, dan penggunaan Frasa Nomina (FN) berfungsi sebagai objek.

\section{PENUTUP}

Penelusuran jejak bahasa Proto-Austronesia pada tataran fonologi dan morfologi di Prasasti Gunung Tua (Lokanātha) menunjukkan bahwa kata juru dan tatkala merupakan kata serapan dari bahasa Sanskerta, sedangkan kata pānḍai dan barbwat merupakan kata turunan dari bahasa Proto-Austronesia. Pada tataran fonologi, kata juru atau 'orang pandai' berasal dari kata jūr atau 'tua (jompo atau orang tua)', yang mengalami perubahan bunyi karena penambahan fonem di akhir kata (paragog). Kata pāṇại atau 'pandai (terampil)' berasal dari kata * pandai atau 'pandai (terampil)', yang mengalami pewarisan inovasi dengan berubahnya vokal pendek menjadi vokal panjang. Perubahan vokal tersebut merupakan pengaruh Bahasa Sanskerta terhadap tata bahasa Melayu Kuno. Pada tataran morfologi, kata barbwat terbentuk dari morfem terikat (prefiks) dan morfem bebas, dan kata tātkālá pun terbentuk dari dua morfem.

Pada tataran sintaksis, diketahui bahwa Prasasti Gunung Tua (Lokanātha) yang berbahasa Melayu Kuno ini menunjukkan struktur kalimat aktif intarnsitif dengan formula "K $\rightarrow$ FAdv + Spes + I + Komp". Teks pada Prasasti Gunung Tua (Lokanātha) ini masih banyak menunjukkan unsur penggunaan Bahasa Sanskerta, baik dari kata, kata turunan, maupun kalimatnya. Akan tetapi, struktur kalimatnya secara signifikan memperlihatkan penggunaan Bahasa Melayu Kuno.

\section{UCAPAN TERIMA KASIH}

Artikel ini merupakan bagian dari tesis yang berjudul "Jejak Bahasa Proto-Austronesia pada Prasastiprasasti Berbahasa Melayu Kuno yang berasal dari Kepurbakalaan Hindu-Buddha Padang Lawas, Sumatera Utara". Penulis mengucapkan terima kasih kepada Dr. Dwi Widayati, M.Hum. selaku pembimbing 1 dan Dr. Mulyadi, M.Hum. selaku pembimbing 2 yang telah membimbing penulis sehingga dapat terselesaikan artikel ini. 


\section{DAFTAR PUSTAKA}

Adelaar, A. K. 1992. Proto Malayic: The Reconstruction of Its Phonology And Parts of Its Lexicon and Morphology. Canberra, Australia: Department of Linguistics, Research School of Pasific Studies, The Australian National University.

Adelaar, A. K. 2000. "Malay: A Short History." Oriente Moderno 19(80)(2):225-42.

Adelaar, A. K. 2010. "Language Documentation in The West Austronesian World and Vanuatu: An Overview."

Pp. 12-44 in Endangered Languages of Austronesia, edited by Florey Margaret. New York: Oxford University Press.

Adhiti, Ida Ayu Iran. 2019. "Kajian Linguistik Historis Komparatif Pada Pola Perubahan Bunyi." Kulturistik: Jurnal Bahasa Dan Budaya 3(2):75-85.

Arsyad, Saida Gani. Berti. 2018. "Kajian Teoritis Struktur Internal Bahasa (Fonologi, Morfologi, Sintaksis, Dan Semantik)." 'A Jamiy, Jurnal Bahasa Dan Sastra Arab 7(1):1-20.

Benjamin, Geoffrey. 2009. "Affixes, Austronesian and Iconicity in Malay." Bijdragen Tot de Taal-, Land- En Volkenkunde 165(2/3):291-323.

Bosch, F. D. 1930. "Verslag van Een Reis Door Sumatra." OV 1930 Bijlage C 133-57.

Crowley, Terry dan Claire Bowern. 2010. An Introduction to Historical Linguistics. Fourth Edi. New York: Oxford University Press.

Damais, Louis-Charles. 1955. "Etudes d'épigraphie Indonésienne, IV: Discussion de La Date Des Inscriptions."

Pp. 1-290 in BËFEO. Vol. XLVII. Paris: Ecole Francaise d'Extreme Orient.

Griffiths, Arlo. 2014. "Inscriptions of Sumatra III: The Padang Lawas Corpus Studied Along with Inscriptions from Sorik Merapi (North Sumatra) and from Muara Takus (Riau)." Pp. 211-53 in History of Padang Lawas II: Society of Padang Lawas (mid-9th-13th century CE), edited by D. Perret. Paris: Association Archipel.

Haegeman, L. 1994. Introduction to Goverment and Binding Theory. Oxford: Blackwell Publishing.

Hayes, Bruce. 2009. Introductory Phonology. Southern Gate, Chichester, West Sussex: Blackwell Publishing.

Hidayatullah, Moch Syarif. 2012. "Bustan Al-Katibin: Pengaruh Tata Bahasa Arab Dalam Tata Bahasa Melayu." Jurnal Manassa Manuskripta 2(1):53-77.

Ino, La. 2015. "Pemanfaatan Linguistik Historis Komparatif Dalam Pemetaan Bahasa-Bahasa Nusantara." Retorika: Jurnal IImu Bahasa 1(2):365-78.

Keraf, Gorys. 1996. Linguistik Bandingan Historis. Jakarta: Gramedia Pustaka Utama.

Leben, William R. dan Orrin W. Robinson. 1977. "Upside-Down Phonology." Language 53(1):1-20.

Lieber, Rochelle. 2009. Introducing Morphology. Cambridge: Cambridge University Press.

Monier-Williams, Sir Monier. 1956. A Sanskrit-English Dictionary. 1st ed. London: Oxford University Press.

Nasoichah, Churmatin. 2009. "Tokoh Suryya (Juru Pandai) Dalam Penulisan Prasasti Gunung Tua (Bhatara Lokanatha)." Berkala Arkeologi Sangkhakala 12(24):113-27.

Nasoichah, Churmatin. 2020. "Kajian Linguistik Historis Komparatif Terhadap Bahasa Melayu Kuno Pada Penulisan Prasasti Panai." Purbawidya 9(1):15-30.

Nida, Eugene A. 1949. Morphology The Descriptive Analysis of Words. Ann Arbor: The University of Michigan Press.

Pusposari, Dewi. 2017. "Kajian Linguistik Historis Komparatif Dalam Sejarah Perkembangan Bahasa Indonesia." Jurnal Inovasi Pendidikan 1(1):75-85.

Setianingsih, R., E. Soedewo, D. Sutrisna, dan S. Purba. 2003. "Prasasti Dan Bentuk Pertulisan Lain Di Wilayah Kerja Balai Arkeologi Medan." in Berita Penelitian Arkeologi No. 10. Medan: Balai Arkeologi Medan.

Sudaryanto. 1992. Metode Linguistik: Ke Arah Memahami Metode Linguistik. Yogyakarta: Gadjah Mada University Press.

Sudaryanto. 2015. Metode Dan Aneka Teknik Analisa Bahasa. Yogyakarta: Sanata Dharma University Press.

Sudirman, AM. 2005. "Refleksi Proto-Austronesia Pada Bahasa Lampung." Litera 4(2):221-34.

Utomo, Bambang Budi. 2007. Prasasti-Prasasti Sumatra. Jakarta: usat Penelitian dan Pengembangan Arkeologi Nasional. 
Utomo, Bambang Budi. 2017."Bhatara Lokanatha dari Gunung Tua." Diunduh 15 Januari 2021 (https://arkenas.kemdikbud.go.id/contents/read/article/rvh06b_1510555637/bhatara-lokanatha-dari gunung- tua\#gsc.tab=0)

Verhaar, J. W. M. 2012. Asas-Asas Linguistik Umum. Yogyakarta: Gadjah Mada University Press.

Wurm, S. dan B. Wilson. 1975. English Finderlist of Reconstructions In Austronesian Languages (PostBrandstetter). Canberra, Australia: Pacific Lingistics, Department of Linguistics, School of Pacific Studies, The Australian National University. 